\title{
Digital Futures: Lumen Big Reveal
}

\author{
Irini Papadimitriou \\ V\&A \\ UK \\ i.papadimitriou@vam.ac.uk
}

\author{
Laura Dekker \\ Artist \\ UK \\ laura@heretohere.co.uk
}

\author{
Jack Addis \\ The Lumen Prize \\ UK \\ jack@lumenprize.com
}

Karl Singporewala
Artist
UK
karl@singporewala.co.uk

\author{
Andy Lomas \\ Artist \\ UK \\ andylomas@gmail.com
}

\author{
Patrick Tresset \\ Artist \\ UK \\ tressetp@gmail.com
}

\begin{abstract}
As part of EVA London 2017, Lumen Prize for Digital Art and V\&A Digital Futures are coming together with a special event presenting a series of installations, networking and the announcement of the 2017 Lumen Prize Longlist.
\end{abstract}

Lumen Prize. V\&A. Digital Futures. Artists. Digital art.

\section{INTRODUCTION}

Digital Futures (Papadimitriou 2016) is a mobile and open platform for displaying and discussing work by researchers, artists, designers, companies and other professionals working with art, technology, design, science and beyond. The programme started at the V\&A in 2012 in order to enable collaboration and exchange, but also to create a flexible space to share artistic processes, academic research and engage with art, design, technology and contemporary issues. Bringing together people from different backgrounds and disciplines has been a central part to the programme. Digital Futures is not fixed to a place; instead, it is an open and mobile platform that changes continuously depending on participants, partners, themes and more, and exploring ideas from different perspectives.

Considering all the above, Digital Futures shares common ground with the Lumen Prize, the annual digital arts award that presents and celebrates the very best art created digitally. Lumen, which is also dedicated to provide a network in the UK and beyond, as well as opportunities to artists, has been presenting groundbreaking projects, but also activities where artists can share research and processes with audiences and inspire younger generations.

The Lumen Prize (http://lumenprize.com) is the global award and tour for artists working with technology. Now in its sixth year, Lumen has disbursed over $\$ 40 \mathrm{k}$ in prize money and staged over 30 shows globally. Its aim is to raise the understanding, appreciation and enjoyment of digital art worldwide.

As part of EVA London 2017, developing from EVA London 2016 (Lambert 2016), Lumen Prize for Digital Art and V\&A Digital Futures are coming together with a special event presenting a series of installations, networking and the announcement of the 2017 Lumen Prize Longlist.

\section{ANDY LOMAS: CONSTRAINED FORMS}

This is the latest stage of an on-going body of work called 'Morphogenetic Creations' that explores how complex organic structures can be created emergently using digital simulation of growth processes. Forms are created using rules for cellular division and interaction: an artificial biology implemented in-silico. In these structures, several environmental constraints influence the growth processes, such as to restrict growth when overhangs get beyond given threshold angles and having a limited supply of nutrient that cells need to grow. Although all the cells have the same basic properties, these constraints make cells in different regions develop in different ways. Each form starts as an initial tube of cells that transforms over time to create intricate alien but familiar structures, often reminiscent of plants and fungi grown in arid environments. 


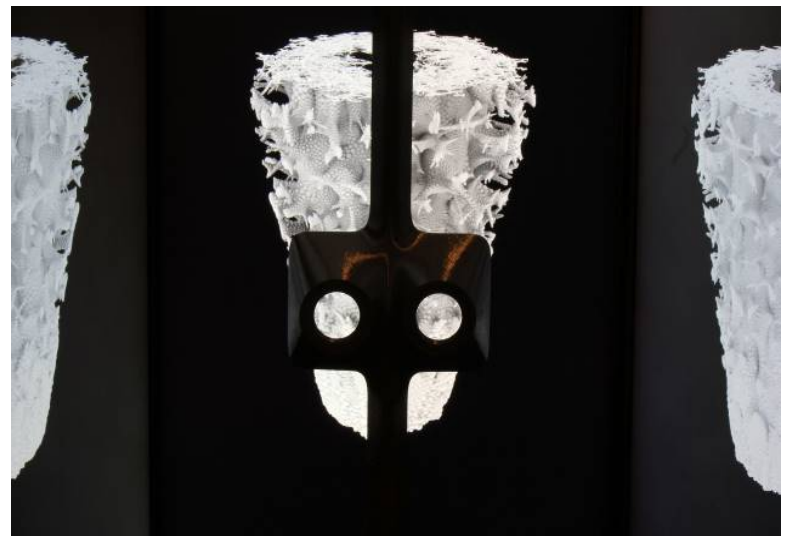

Figure 1: Constrained Forms Stereo Installation - Andy Lomas

The work is presented as an installation piece using front surface mirrors, video monitors, 3D printed parts and dual high definition digital video streams. The work is designed so that both $2 \mathrm{D}$ and $3 \mathrm{D}$ versions of the forms are readily viewable: the original digitally created images in the video screens (2D renders of 3D data) which, when seen through the mirrors, use stereopsis to create the psychological perception of three-dimensional structure. The artist wrote the software used to create the work.

\section{KARL SINGPOREWALA}

Below is a short explanation on the genesis and production of Dial $\mathrm{M}$ for Monument, a sculpture by Karl Singporewala.

Digitalised production: My life, a laptop, a lasercutter and the cracks between time

Deception and Love, could be another name for the piece Dial M for Monument...

In early 2012, M asked me to skip submitting an artwork for the Royal Academy of Arts Summer Exhibition that year due to my on-going issues with time management. I was busy with architecture, building projects on site, further education (my ARB/RIBA part 3 exams) and with a young family at home; I was already not enough butter spread thinly over too much bread. Determined to still produce a piece of work for the Summer Exhibition (and some misplaced pride to maintain my record of acceptance to the summer show since 2007), I resigned myself to making a piece by stealth in the cracks between time*.

Using a laptop loaded with Microstation (an architect's fastest, most stable CAD software) and a sketchbook I set about designing a 3D sculpture from 2D components which could be laser cut late in the evening and then slotted together without any adhesive on the commuter train the next day. On reflection, the secrecy required to produce the piece (and subsequent editions) ended up becoming a self-imposed brief which I still employ to this day. My guilt in hiding something from $M$ sculpture made from one simple 2D CAD drawing became a dedication to her.

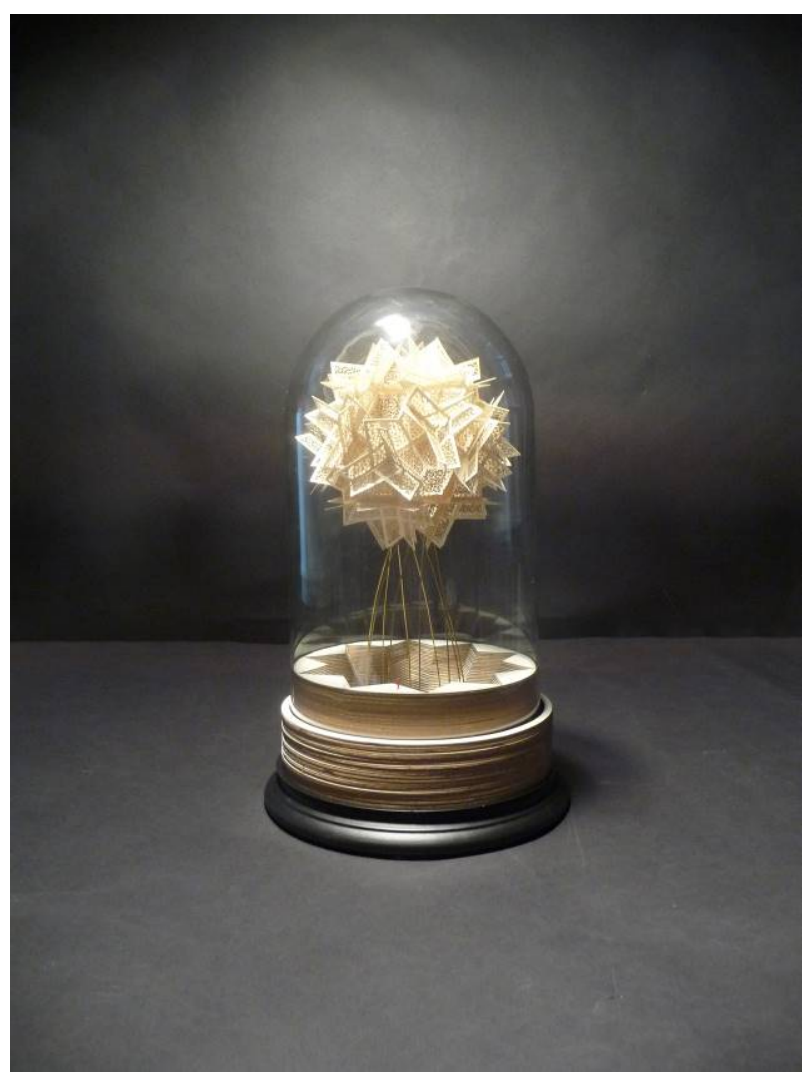

Figure 2: Dial M for Monument 01 - Karl Singporewala

Dial $\mathrm{M}$ for Monument is a beautiful, complex, intricate and prickly sculpture made from one simple 2D CAD drawing which is then laser-cut multiple times and locked together to form a dodecicosidodecahedron. I am the 1:200 scale red figure at its base, she is my muse.

Cracks in time (anywhere, any place) - After family is asleep; on the commuter train; Lunch break; The journey to and from meetings; etc.

\section{LAURA DEKKER}

Laura Dekker is a British artist whose work explores the reciprocal roles of technologies in how we experience, make sense of, and construct our world. Her recent work investigates how discourses of emerging technologies - media representations in particular - affect their reception and development, at a personal, commercial and social level, as well as the ethics and public policy that evolve with them. 


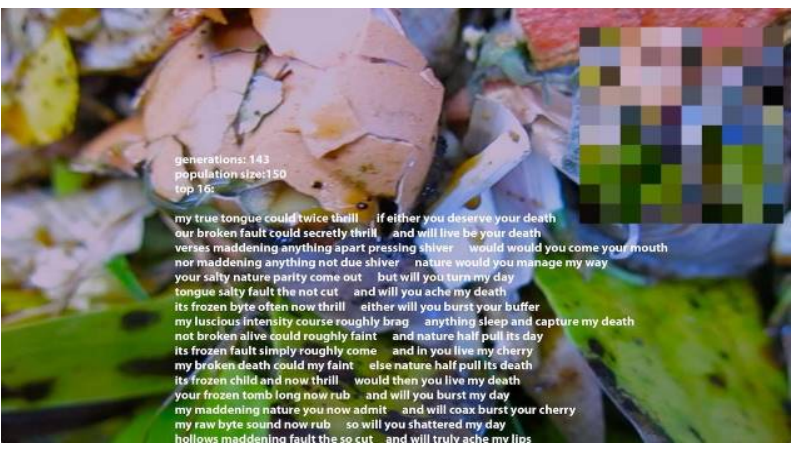

Figure 3: Salty Bitter Sweet - Laura Dekker

Laura examines these ideas through robotic and interactive works, combining physical materials, layered video, audio and techniques developed during many years' as a research scientist in 3D imaging and artificial intelligence. Her works aim to engage the viewer-participant with a sensorially rich and provocative experience: virtual objects can intrude into the 'actual' world, or objects are activated with a kind of primitive consciousness, creating an oscillation between the virtual and the actual. There is always a performative aspect - at the point of production, reception, or both.

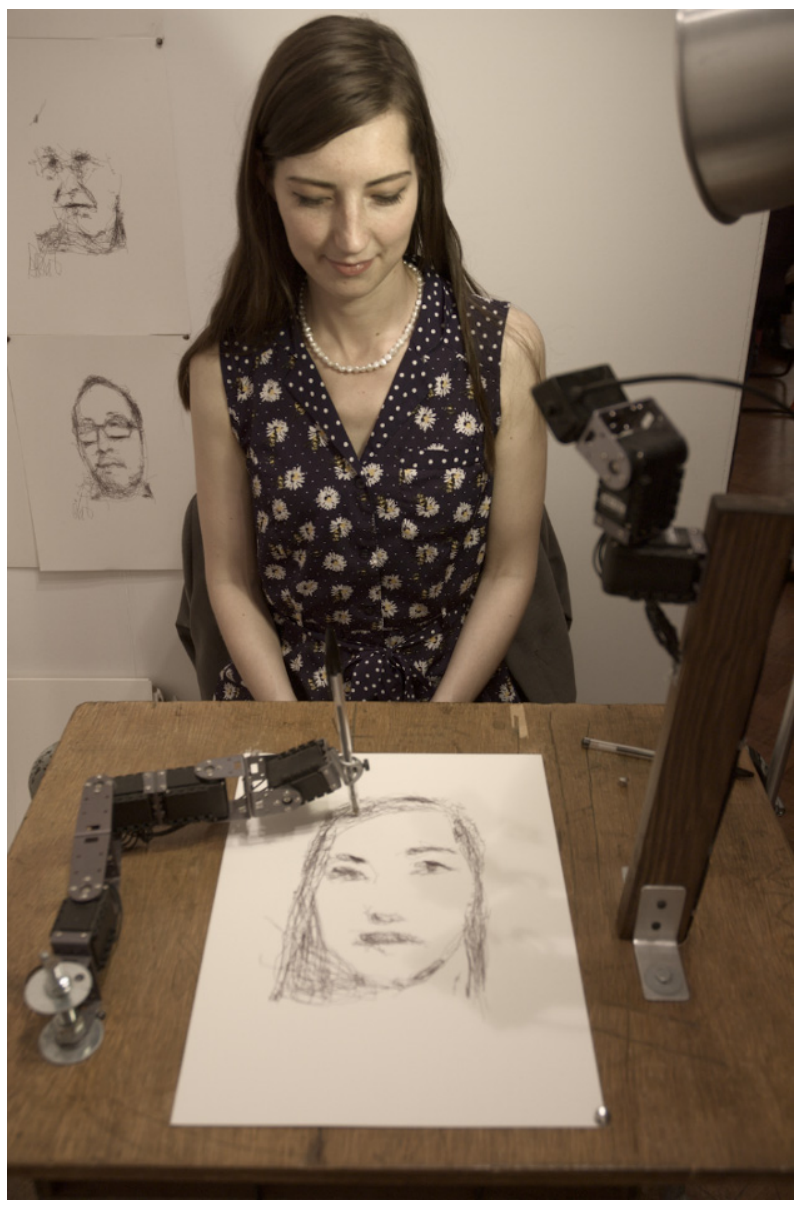

Figure 4: Amy, drawn by Paul-II, photograph by Steph Horak
Laura's work is shown internationally at festivals, museums, parkland, historical sites and urban public spaces. She often works collaboratively with the London-based art collective XAP, whose diverse practices come together in experimental projects and performances.

\section{PATRICK TRESSET}

Patrick Tresset is a London based artist who develops and presents theatrical installations with robotic agents as actors which are evocations of humanness. Tresset's installations use computational systems that introduce artistic, expressive and obsessive aspects to robots' behaviour. These systems are influenced by research into human behaviour, more specifically how artists make marks that depict how humans perceive artworks. Tresset also develops robots and autonomous computational systems, such as RNP (Robot named Paul), to explore the painting and drawing practice.

RNP is a drawing robot that reacts to a human sitting in front of it by making marks on the paper. The sitter only sees the robot alternating between observing and drawing, sometimes pausing. As the model in a life drawing class, the sitter is passive, leaving the robot to take what is perceived as the artistic role. RNP was originally developed by Patrick to palliate a debilitating painter's block. As such it could be seen as a creative prosthetic or a behavioural self-portrait. Even if the way the robot draws is based on Patrick's technique, its style is not a pastiche, but rather an interpretation influenced by the robot's characteristics.

\section{REFERENCES}

Lambert, N. (2016) The Lumen Prize at EVA London 2016. In J. P. Bowen, G. Diprose, \& N. Lambert (eds.), EVA London 2016: Electronic Visualisation and the Arts, p. 286. BCS, Electronic Workshops in Computing. DOI: 10.14236/ewic/EVA2016.57

Papadimitriou, I. (2016) Digital Futures. Blog, V\&A, London, UK. http://www.vam.ac.uk/blog/tag/digitalfutures (accessed 24 May 2017). 